\title{
AndHD
}

\section{Sosyal Yardımlaşma ve Dayanışma Vakıflarının 2022 Sayılı Kanun Kapsamındaki İşlemlerine Karşı Açılan Davalarda Görevli Yargı Yeri Sorunu ${ }^{(*)}$}

The Issue of the Court of Competent Jurisdiction in the Lawsuits Related with the Actions of Social Assistance and Solidarity Foundations According

to the Law No. 2022

\section{Mücahit GÜLŞEN}

Hukuk Müşaviri

Aile ve Sosyal Hizmetler Bakanliğl

\section{Anahtar Kelimeler \\ Sosyal Yardımlaşma ve Dayanışma Vakfi, \\ Idari Makam, \\ İdari İslem, \\ Ícrailik, \\ İdari Yargı.}

\section{Keywords}

Social Assistance and Solidarity Foundation,

Administrative

Authority,

Administrative Action,

Enforcement,

Administrative

Jurisdiction.
Öz

Sosyal yardımlaşma ve dayanışma vakıfları, 5737 sayılı Vakıflar Kanunu'na göre özel hukuk tüzel kişileridir. 2022 sayılı Kanun uyarınca, engelli aylığı ve yaşlı aylığı başvuruları bu vakıflara yapılmaktadır. Sosyal yardımlaşma ve dayanışma vakıfları tarafından, aylık başvurularının kabulüne veya reddine karar verilmektedir. Bunun yanında, aylık bağlandıktan sonra yapılan incelemeler neticesinde aylıkların kesilmesi de söz konusudur.

Aylık başvurusunun reddi ve aylığın kesilmesi işlemleri, kişilerin menfaatini ihlâl eden idari işlemlerdir. Bu idari işlemlerin iptali için açılan davalarda, bir özel hukuk tüzel kişisi tarafindan idari işlem tesis edilemeyeceği yönündeki yargı kararları nedeniyle sorunlar yaşanmaktadır. Hâlbuki idare hukukunda, yasalarla yetkilendirilmiş özel hukuk tüzel kişilerince de idari işlem tesis edilebileceği kabul edilmektedir. Bu makalede, aylık başvurusunun reddi ve aylığın kesilmesi işlemlerine ilişkin davalarda görevli yargı yeri konusu incelenmiştir.

\begin{abstract}
Social assistance and solidarity foundations are legal entities according to Foundations Law No. 5737. According to Law No. 2022, disability pension and elderly pension applications are made to these foundations. Social assistance and solidarity foundations decide to accept or reject the pension applications. Furthermore, as a result of the controls, the pensions can be cancelled.

Rejection of the pension application and the cancellation of the pension are administrative actions that violate theinterests of the persons. In the lawsuits filed for the annul ment of these administra tive acts, problems arose regarding the determination of the court of competent jurisdiction in this dispute, due to the judicial decisions stating that foundations cannot take administrative action. However, in administrative law, it is accepted that administrative action can be made by founda tions authorized by laws. In this article, the court of competent jurisdiction in the lawsuits regarding the rejection of the pension application and the cancellation of the pension has been studied.
\end{abstract}




\section{GİRİș}

Sosyal yardımlaşma ve dayanışma (SYD) vakıfları, 3294 sayılı Sosyal Yardımlaşma ve Dayanışmayı Teşvik Kanunu'nun 7'nci maddesine göre, bu Kanun'un amacına uygun faaliyet yürütmek ve ihtiyaç sahibi vatandaşlara nakdi ve aynî yardımda bulunmak üzere her ilde ve ilçede kurulmuştur ${ }^{1}$.

4721 sayılı Türk Medeni Kanunu2'na (TMK) göre kurulan bu vakıflar, 5737 sayılı Vakıflar Ka nunu'nun ${ }^{3}$ 4'üncü maddesine göre özel hukuk tüzel kişisidir' ${ }^{4}$. SYD vakıflarının kuruluş amacı, 3294 sayılı Kanun'da belirtilmekledir. Bununla birlikte diğer kanunlarla bu vakıflara çeşitli görevler verilmiştir.

2022 sayıl1 65 Yaşını Doldurmuş Muhtaç, Güçsüz ve Kimsesiz Türk Vatandaşlarına Aylık Bağ-

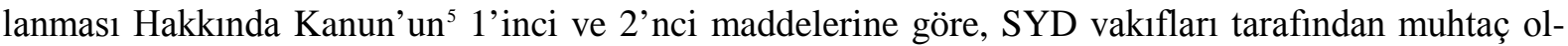
duğuna karar verilenlere engelli aylıkları ve yaşlı aylıkları bağlanmaktadır. 2022 sayılı Kanun'un 3' üncü maddesine göre, bu aylıkların bağlanması amacıyla SYD vakıflarına yazılı olarak başvuru yapılması gerekmektedir. Bu vakıflar tarafından başvurusu kabul edilen kişilere, Aile ve Sosyal Hizmetler Bakanlığı ${ }^{6}$ tarafından aylıklar ödenmektedir. 2020 yılında engelli aylığı, engelli yakını aylığı veya yaşlı aylığı ödenen kişi sayısı 1.545.418 olmuştur?

2022 sayılı Kanun'un uygulama yönetmeliği olan 65 Yaşını Doldurmuş Muhtaç, Güçš̈z ve Kimsesiz Türk Vatandaşları ile Engelli ve Muhtaç Türk Vatandaşlarına Aylık Bağlanması Hakkında Yönetmelik'in ${ }^{8}$ (Yönetmelik) 8 'inci maddesine göre, söz konusu aylık başvurularının kabulüne veya reddine, sosyal yardımlaşma ve dayanışma vakıflarının yönetim organı olan mütevelli heyeti tarafından karar verilmektedir. Bahse konu Yönetmelik'in 10'uncu maddesinin 3'üncü fikrasına göre mütevelli heyetinin verdiği kararlara yapılacak itirazlar da yine aynı mütevelli heyeti tarafından değerlendirilmektedir. Bunun yanında, ödenmekte olan aylıkların kesilmesi de söz konusudur. Yönetmelik'in 11 'inci maddesinin 2'nci fikrasında, aylıkların kesileceği durumlar sayılmıştır.

2022 sayılı Kanun kapsamında ödenen engelli aylıkları, engelli yakını aylıkları ve yaşlı aylıkları ile ilgili olarak başvurunun kabulü, başvurunun reddi veya aylığın kesilmesi hususlarında sosyal yardımlaşma ve dayanışma vakıfları tarafindan işlem tesis edilmektedir. Bu işlemlerden aylık başvurusunun reddi ile aylığın kesilmesi işlemleri, kişilerin menfaatini ihlâl eden ve bir davaya konu olabilecek işlemlerdir.

Daha öncesinde idari yargıda görülen bu uyuşmazlıkların çözümünde Uyuşmazlık Mahkemesinin T. 08.07.2019, E. 2019/279, K. 2019/422 sayılı kararı ile adli yargının görevli olduğuna karar verilme si bazı sorunlara yol açmıştır. Bu çalışmada, bir özel hukuk tüzel kişisi olan sosyal yardımlaşma ve dayanışma vakıfları tarafından tesis edilen bu işlemlerin iptali amacıyla hangi yargı yerinde dava açılacağı konusu incelenecektir.

\footnotetext{
14.06.1986 tarihli ve 19134 sayılı Resmî Gazete.

08.12.2001 tarihli ve 24607 sayılı Resmî Gazete.

27.02.2008 tarihli ve 26800 sayılı Resmî Gazete.

21.07.2017 tarihli ve 30130 sayılı Resmî Gazete'de yayımlanan, Yargıtay İçtihadı Birleștirme Hukuk Genel Kurulunun T. 09.06.2017, E. 2016/3, K. 2017/4 sayılı kararında, 3294 sayılı Sosyal Yardımlaşma ve Dayanışmayı Teşvik Kanunu ile kurulan sosyal yardımlaşma ve dayanışma vakıflarının özel hukuk tüzel kişiliğine sahip olduğu ve (mülga) Aile ve Sosyal Politikalar Bakanlığına bağlı olmadıkları ifade edilmiştir.

$5 \quad$ 10.07.1976 tarihli ve 15642 sayılı Resmî Gazete.

62022 sayılı Kanunda, Aile ve Sosyal Politikalar Bakanlığı ifadesi yer almakta olup 09.07.2018 tarihli ve 30473 sayılı Resmî Gazete'de yayımlanan 703 sayılı KHK ile bu Bakanlık kapatılmış ve Bakanlığın görevleri 10.07.2018 tarihli ve 30474 sayılı Resmî Gazete'de ya yımlanan 1 sayılı Cumhurbaşkanlığı Kararnamesi uyarınca Aile ve Sosyal Hizmetler Bakanlığı tarafından yürütülmektedir.

7 Aile, Çalışma ve Sosyal Hizmetler Bakanlığı, 2021 Yılı Performans Programı, s. 131-132.

(https://www.ailegov.tr/media/72689/acshb-2021-yili-performans-programi.pdf, E.T.: 21.11.2021). 2020 y1lında, 825.573 kişiye yaşlı aylığı; 346.752 engelli, 277.553 bakıma muhtaç engelli olmak üzere toplamda 624.305 kişiye engelli aylığı, 95.540 kişiye engelli yakını aylığı ödenmiştir. 2022 sayılı Kanun’un geçici 2. maddesi kapsamında 163 kişiye silikozis aylığı ödenmektedir. Buna karşın silikozis aylığı için başvuru alınmadığı için bu çalışmada değinilmemiştir.

$8 \quad 25.01 .2013$ tarihli ve 28359 sayılı Resmî Gazete.
} 


\section{TÜRK HUKUKUNDA VAKIFLAR}

\section{A. Genel Olarak}

Osmanlı Devleti'nde, güvenlik ile adalet hizmetleri dışındaki tüm hizmetlerin yürütülmesinde vakıflar önemli roller yerine getirmiştir. Bu çerçevede Osmanlı Devleti'nde vakıflar tarafından yürütülebilen başlıca hizmetler; eğitim hizmetleri, sağlık hizmetleri, şehircilik hizmetleri, çevre hizmetleri, sosyal hizmetler ve dini hizmetlerdir' ${ }^{9}$. Bu hizmetleri sunmak için vakfedenler tarafindan vakfın amacına harcanması için gelirler ve servetler tahsis edilmiş ve bunun sonucunda binlerce vakıf kurulmuştur ${ }^{10}$.

Günümüzde de önemli hizmetler yerine getiren vakıflar, belirli bir amacı gerçekleştirmek üzere Ka nun'daki şekil kurallarına uygun olarak özgülenmiş mal topluluğu olup kurum mahiyetinde bir tüzel kişi türüdür. 743 sayılı Türk Kanunu Medenisi'nde"11, 13.07.1967 tarihli ve 903 sayılı Kanun ile değişiklik yapılıncaya kadar "tesis" terimi "vakıf" terimi yerine kullanılmıştır. Bu değişiklikle birlikte daha eski bir terim olan ve Osmanlı Devleti'nde kullanılan vakıf terimi yeniden mevzuatta yer almıştır ${ }^{12}$.

TMK'nın 101'inci maddesine göre gerçek veya tüzel kişilerin yeterli mal ve hakları belirli ve sür rekli bir amaca özgülemeleriyle oluşan tüzel kişiliğe sahip mal toplulukları olan vakıflar, 5737 sayılı Vakıflar Kanunu'nun 4'üncü maddesine göre özel hukuk tüzel kişiliğine sahiptiri ${ }^{13}$ Vakıflar Kanunu, vakıfları beşe ayırmaktadır. Kanunda vakıflar; mazbut, mülhak, cemaat ve esnaf vakıfları ile yeni va kıflar olarak düzenlenmiştir.

Mazbut vakıflar, kısaca, Vakıflar Genel Müdürlüğünce yönetilen vakıflardır. Mülhak vakıflar, mülga Türk Kanunu Medenisi’nin yürürlük tarihinden, yani 04.10.1926 tarihinden önce kurulmuş ve yönetimi vakfedenlerin soyundan gelenlere şart edilmiş vakıflardır. Cemaat vakfi, vakfiyeleri ${ }^{14}$ ol up olmadiğına bakılmaksızın 05.06.1935 tarihli ve 2762 sayılı Vakıflar Kanunu ${ }^{15}$ gereğince tüzel kişilik kazanmış, mensupları Türkiye Cumhuriyeti vatandaşı olan Türkiye'deki gayrimüslim cemaatlere ait vakıflardır. Esnaf vakıfları, 2762 sayılı Vakıflar Kanunu'nun yürürlüğe girdiği 13.06.1935 tarihinden önce kurulmuş ve esnafin seçtiği yönetim kurulu tarafından yönetilen vakıflardır. Yeni vakıf ise mülga 743 sayılı Türk Ka nunu Medenisi ile TMK hükümlerine göre kurulan vakıflardır. Ancak yeni vakıf tanımında, vakfın kurulduğu dönem dışında, vakfın bir özelliğine ve faaliyet alanına ilişkin bir bilgiye ver verilmemektedir ${ }^{16}$.

Vakıflar Kanunu dışında, TMK'da adı geçen vakıflar da bulunmaktadır. TMK'nın 117'nci maddesinin 3'üncü fikrasında ve 520'nci maddesinin 2'nci fikrasına göre kamuya yararlı vakıflar, gelirle rinin yarısı veya daha fazlasını kamu hizmeti niteliğindeki işler için ayıran vakıflardır ${ }^{17}$. Kamuya ya rarlı vakıf ifadesinden vergi muafiyeti tanınmış vakıflar kastedilmektedir ${ }^{18}$.

TMK'nın 110'uncu maddesinde düzenlenen, çalışanlara ve işçilere yardım vakıflarının kurulmasında, iş yerinin personeline, nakit yardımı, konut desteği, emeklilik ödemesi, sağlık desteği gibi menfaatlerin sağlanması amaçlanmaktadır ${ }^{19}$.

\footnotetext{
ÖĞÜZ, Mehmet Tufan: Türk Hukukunda Vaklf Tüzel Kişiliğinin Hukuki Esasları, Beşir Kitabevi, İstanbul, 2007, s. 6.

10 AKIPEK, Jale / AKINTÜRK, Turgut / ATEŞ, Derya: Türk Medeni Hukuku, 1. Cilt, 16. Baskı, Beta Basım Yayın, İstanbul, 2020, s. 666.

11 04.04.1926 tarihli ve 339 sayılı Resmî Gazete.

12 AKIPEK / AKINTÜRK / ATEŞ, s. 664-665.

13 OĞUZMAN, Kemal / SELIÇİ, Özer / OKTAY-ÖZDEMIR, Saibe: Kişiler Hukuku Gerçek ve Tüzel Kişsiler, 17. Baskı, Filiz Kitabevi, İstanbul, 2018, s. 390.

145737 sayılı Vakıflar Kanunu'nun 3'üncü maddesine göre vakfiye; mazbut, mülhak ve cemaat vakıflarının malvarlığını, vakıf şartlarını ve vakfedenin isteklerini içeren belgelerdir.

15 13.06.1935 tarihli ve 3027 sayılı Resmî Gazete.

16 OĞUZMAN / SELIÇ்̇ / OKTAY-ÖZDEMİ, s. 391.

17 AKIPEK / AKINTÜRK / ATES, s. 677.

18 OĞUZMAN / SELIĊ̇̇ / OKTAY-ÖZDEMİ, s. 391.

19 EM, Ali: Türk Hukuk Sisteminde Vakıflar, Turhan Kitabevi, Ankara, 2006, s. 18.
} 
TMK'nın 372'nci maddesinde tanımı yapılan aile vakıflarının ise diğer vakıflardan tek farklı olduğu husus vakfın amacıdır ve bu amaç doğrudan TMK'da belirtilmiştir. Aile vakıfları, "aile bireylerinin eğitim ve öğrenimleri, donanım ve desteklenmeleri ve bunlara benzer amaçların gerektirdiği harcamaların yapılması için" kurulabilir ${ }^{20}$.

Vakıf türlerinden çalışmanın konusu olan SYD vakıfları, ilk olarak 1986 yılında, 743 sayılı Türk Kanunu Medenisi'ne ve bu Kanun'u yürürlükten kaldıran TMK hükümlerine göre kurulmaları nedeniyle "yeni vakıf" statüsündedir. Yeni vakıflar, TMK hükümleri çerçevesinde faaliyet yürütmekte olup bu vakıfların yönetim organı vakıf senetlerine göre oluşturulur ${ }^{21}$.

1982 Anayasası'nın 33'üncü maddesinin 1'inci ve 7'nci fikraları birlikte göz önüne alındığında herkes, önceden izin almaksızın vakıf kurma hürriyetine sahip olduğu görülmektedir. Bu durumda hem gerçek kişilerin hem de tüzel kişilerin vakıf kurması mümkündür ${ }^{22}$.

Vakıfların tüzel kişilik kazanması ise TMK'nın 102'nci maddesi uyarınca, kurulan vakfın yerleşim yerindeki asliye hukuk mahkemesinde tutulan sicile tescil edilmesi ile sağlanır. Yine aynı maddeye göre vakıf kurma iradesi, resmî senetle veya ölüme bağlı tasarrufla açıklanır. Tesciline karar verilen vakıf, TMK'nın 104'üncü maddesi gereğince ayrıca Vakıflar Genel Müdürlüğünde tutulan merkezi sicile kaydedilir ${ }^{23}$.

Resmi senetle vakıf kurma iradesinin açıklandığı durumlarda, vakıf senedinde ${ }^{24}$ vakfin adı, amacı, bu amaca özgülenen mal ve haklar, vakfın örgütlenme ve yönetim şekli ile yerleşim yeri gösterilmesi TMK'nın 106'ncı maddesi ile zorunlu tutulmuştur.

Vakıfların yönetilmesini ve karar almasını sağlamak amacıyla vakfın bir yönetim organının bur lunması, yasalar ile zorunlu hale getirilmiştir. TMK'da ve Vakıflar Kanunu'nda, vakıf organlarından sadece yönetim organı açıkça ifade edilmiştir ${ }^{25}$. Bunun yanında, vakfın amacının gerçekleştirilmesinde yarar sağlayacak ise vakıfların diğer organları oluşturulabilir. Vakfeden, vakıf senedinde gerekli gördüğü bu diğer organları gösterebilir. Genel kurul, denetim kurulu, danışma kurulu, diğer organlara örnek olarak sayılabilir ${ }^{26}$.

Vakıfların gelirlerini, taşınmazlarını ve diğer varlıklarını senette belirtilen amaca uygun olarak tasarruf edip etmedikleri, Vakıflar Genel Müdürlüğünce ve vakıfların ilişkili olduğu kuruluşlarca denetlenir. Vakıfların kuruluşlarca ilişkisi genel olarak bir kanun hükmüyle kurulduğu için, bu kuruluşların denetimyetkisinin çerçevesi olan ilgili kanunda belirtilir ${ }^{27}$.

TMK'nın 117'nci maddesinin 3'üncü fikrasında, kamuya yararlı veya özel kanunlarla kurulan vakıflar hakkındaki özel hükümleri saklı tutulmuş olup özel kanunla kurulan ve kamu hizmeti niteliğinde işler yapan sosyal yardımlaşma ve dayanışma vakıflarını ayrıca incelemek gerekmektedir.

\section{B. Sosyal Yardımlaşma ve Dayanışma Vakıfları}

SYD vakıfları, 3294 sayılı Sosyal Yardımlaşma ve Dayanışmayı Teşvik Kanunu'nun 7'nci maddesi uyarınca illerde ve ilçelerde kurulmaktadır. Günümüzde 922 ilçede ve 81 ilde toplam 1003 adet

\footnotetext{
20 OĞUZMAN / SELIÇ்̇ / OKTAY-ÖZDEMIR, s. 398.

21 SEROZAN, Rona: Medeni Hukuk Genel Bölüm Kişiler Hukuku, 8. Baskı, Vedat Kitapçılı, İstanbul, 2018, s. 514.

22 ÖĞÜZ, s. 15.

23 SEROZAN, s. 514.

24 Vakıflar Kanunu'nun 3'üncü maddesine göre vakıf senedi, "Mülga 743 sayılı Türk Kanunu Medenisi ile 22/11/2001 tarihli ve 4721 sayılı Türk Medenî Kanunu hükümlerine göre kurulan vakffların, malvarlğı̆n ve vakıf şartlarını içeren belgeyi, ifade eder." şeklinde ta nımlanmıștır.

25 AYKUL, Ömer: Yeni Vakıflar Hukuku, 1. Baskı, Seçkin Yayıncılık, Ankara, 2013, s. 105.

26 AYKUL, S. 92.

27 AKIPEK / AKINTÜRK / ATEŞ, s. 692.
} 
SYD vakfı bulunmakta olup yeni bir il veya ilçe kurulması halinde, o yerde bir de SYD vakfı kurulmasi gerekmektedir ${ }^{28}$.

SYD vakıfları, temel olarak, herhangi bir sosyal güvencesi olmayan muhtaç vatandaşlara yardım yapmak ve yoksullukla mücadele amaciyla kurulmuştur. Örneğin, küçük bir destek ${ }^{29}$ ile topluma faydalı hale gelmesi mümkün olan kişilere yardım yaparak yoksullukla mücadele etmek, bu vakıfların görevleri arasındadır. Bu destek, proje desteği olarak nakdî bir ödeme şeklinde de olabilir. Bir berbere tıraş makinesi yardımı veya bir terziye dikiş makinesi yardımı gibi aynî yardım şeklinde de olabilmektedir.

3294 sayılı Kanun'a göre bu vakıfların kuruluş amacı şunlardır ${ }^{30}$ :

- Sosyal güvenlik kuruluşlarına tabi olmayan ve bu kuruluşlardan aylık ve gelir almayan muhtaç vatandaşlara nakdî ve aynî yardımda bulunmak,

- Geçici olarak küçük bir yardım veya eğitim ve öğretim imkânı sağlanması halinde topluma fayda 11 hale getirilecek, üretken duruma geçirilebilecek kişilere yardımda bulunmak,

- Her türlü acil durum ve afetten zarar görenlere yardımda bulunmak,

- Şehit yakınları ile gazilere yardımda bulunmak,

- Sosyal adaleti pekiştirici tedbirler alarak sosyal yardımlaşma ve dayanışmayı teşvik etmek ve ge lir dağılımının adil olmasını sağlamaya yönelik çalışmalar yapmak.

3294 sayılı Kanun dışında diğer kanunlarla da bu vakıflara çeşitli görevler verilmektedir. Örneğin, 2022 sayılı Kanun ile engelli aylığı ve yaşlı aylığı başvurularının alınması ve değerlendirilmesi veya 2828 sayılı Sosyal Hizmetler Kanunu'nun ${ }^{31}$ ek 7 'nci maddesi gereğince engellilerin evde bakımına destek için yapılacak sosyal yardımlara ilişkin iş ve işlemler, SYD vakıflarına kanunla verilen görevler arasındadır.

SYD vakıflarının faaliyetlerini yürütmek için ihtiyaç duyduğu finansman, sosyal yardımlaşma ve dayanışmayı teşvik fonundan karşılanır. Bu vakıfların diğer gelir kaynakları, iktisadi işletmesi bulunan vakıflarda iktisadi işletme gelirleri ve doğrudan bu vakıflara yapılan bağış ve yardımlardır.

Sosyal Yardımlaşma ve Dayanışmayı Teşvik Fonu'nun gelirleri ise 3294 sayılı Kanun'un 4'üncü maddesinde sayılmış olup bunlar; Cumhurbaşkanı kararıyla başka fonlardan aktarılan kaynaklar, genel bütçeden aktarılan pay, trafik para cezası hasılatının yarısı, RTÜK reklam gelirlerinin \%15'i, bağıș ve yardımlardır. Ayrıca, 4842 sayılı Kanun'un ${ }^{32} 38$ ' inci maddesine göre, gel ir ve kurumlar vergisi tahsilat toplamı üzerinden \%2,8'i de bu Fon'un gelirleri arasındadır.

SYD vakıflarının yönetim organı, 3294 sayılı Kanun ile belirlenmiştir. Bu Kanun'un 7'nci maddesinin 2'nci fikrasına göre mülkî idare amirleri vakfın doğal başkanıdır. Diğer bir ifade ile ilçe vakıflarının başkanı kaymakam, il vakıflarının başkanı validir. Vakfın yönetim organı ise vakfın mütevelli heyetidir. Mütevelli heyeti, belediye başkanı, il veya ilçedeki bazı kurum temsilcileri -defterdar, milli eğitim müdürü, sağl1k müdür vb. gibi- ile muhtarı temsilen bir muhtar, sivil toplum kuruluşu temsilcisi ve hayırsever vatandaşlardan oluşmaktadır. Bu düzenlemeye göre mütevelli heyetinde resmi görevliler yanında sivil kişiler de görev yapmaktadır.

28 Aile ve Sosyal Hizmetler Bakanlığı, Sosyal Yardımlar Genel Müdürlüğü, Sosyal Yardımlaşma ve Dayanışma Vakıfları (https://www.aile.gov.tr/sygm/genel-mudurluk/sosyal-yardimlasma-ve-dayanisma-vakiflari/, E.T.: 10.11.2021).

293294 sayılı Kanun'un 2'nci maddesinin 1'inci fikrasında "küçük bir yardım” ifadesi kullanılmakta olup uygulamada bu desteğe “iş kurma desteği” denilmektedir. Bu destek, genel olarak faizsiz bir kredi türü olup girişimcilere ve küçük işletmelere verilen nakdi veya ayni yardımları ifade eder (https://www.aile.gov.tr/sss/sosyal-yardimlar-genel-mudurlugu/gelir-getirici-projeler/, E.T.: 10.11.2021).

30 Bu maddenin 01.12.2004 tarihli ve 5263 sayılı Kanun'un 19'uncu maddesi ile değişmeden önceki hali, "Sosyal Yardımlaşma ve Dayanışmayı Teşvik Fonunda toplanan kaynağın ülke çapında ihtiyaç sahibi vatandaşlara nakdi ve ayni olarak dağıtılmak ve bu Kanunun amacına uygun faaliyet ve çalışmalarda bulunmak üzere her il ve ilçede Sosyal Yardımlaşma ve Dayanışma vakıfları kurulur." şeklindedir.

3127.05 .1983 tarihli ve 18059 sayılı Resmî Gazete.

324842 sayılı Bazı Kanunlarda Değişiklik Yapılması Hakkında Kanun (24.04.2003 tarihli ve 25088 sayılı Resmî Gazete). 
5737 sayılı Vakıflar Kanunu'nun 33'üncü maddesine göre vakıfların denetimi, vakfın yapacağı iç de netim veya bağımsız denetim kuruluşlarına yaptıracağı denetim dışında, Vakıflar Genel Müdürlüğü tarafindan yapılır. Buna ek olarak, 1 sayılı Cumhurbaşkanlığı Kararnamesi'nin ${ }^{33} 73$ 'üncü maddesinin 1. fikra sının (ç) bendine göre Aile ve Sosyal Hizmetler Bakanlığı Sosyal Yardımlar Genel Müdürlüğü, SYD vakıflarının harcamalarını, iş ve işlemlerini araştırmak, incelemek, izlemek ve denetlemek yetkisinesahiptir.

Vakıflar Kanunu'na göre yeni vakıfların yönetim organı vakıf senedine ${ }^{34}$ göre oluşturulur ve vakfın amacı vakıf senedinde belirtilir. Yeni vakıf statüsünde olan SYD vakıflarının yönetim organı ve amacı, 3294 sayılı Kanun'da ve Vakıflara Kanunu'na uygun olarak hazırlanan vakıf senedinde yer almaktadır.

SYD vakıfları, özel hukuk tüzel kişisi olmaları sebebiyle özel hukuk alanında işlem ve eylem yapmaktadırlar. Buna karşın, 2022 sayılı Kanun gibi bazı yasal düzenlemelerle bu vakıflara kamu hukuku alanında da işlem ve eylem yapabilme yetkisi verilmiştir ${ }^{35}$.

\section{SOSYAL YARDIMLAŞMA VE DAYANIȘMA VAKIFLARININ 2022 SAYILI KANUN KAPSAMINDAKİ İŞLEMLERI}

2022 sayılı Kanun'un 3'üncü maddesine göre engelli aylığ ve yaşlı aylığ ${ }^{36}$ başvurularının, ilgilinin adrese dayalı nüfus kayıt sisteminde kayıtlı ikametgâhının bulunduğu ${ }^{37}$ yerdeki il veya ilçe SYD vakfına yazılı olarak yapılması gerekmektedir.

SYD vakfi, Yönetmelik'in 6'ncı maddesi gereğince, ilgili hakkında sosyal inceleme yaparak başvuru formunda beyan edilen bilgiler ile merkezi veri tabanlarından yapılan sorgulamalar doğrultusunda elde edilen bilgilerin doğrulanmasını ve engelli veya yaşlının yaşadığı hanenin genel durumunu yerinde tespit eder ${ }^{38}$.

2022 sayılı Kanun'un 1'inci ve 2'nci maddelerine göre engelli ve yaşlı aylıklarının bağlanabilmesi için ilgili SYD vakfi tarafindan "muhtaçlık kararı" verilmesi gerekmektedir. SYD vakfi tarafindan yapılan inceleme sonucunda ilgilinin muhtaç olduğuna karar verilmesi halinde, Aile ve Sosyal Hizmetler Bakanlığı tarafindan ilgiliye ödeme yapılabilmektedir. Burada, Bakanlığın yetkisinin bağlı yetki ${ }^{39}$ olduğu görülmektedir. Çünkü Bakanlığın aylık ödeme yetkisi öncelikle, vakıf tarafından verilmiş bir muhtaçlık kararı olma sına bağlanmıştır. Buna karşın SYD vakfi tarafından yapılan inceleme sonucunda elde edilen verilere göre ilgilinin muhtaç olmadığına karar verilmesi halinde aylık başvurusu reddedilmekte ve bu durum yine 2022 sayılı Kanun'un 8'inci maddesinin 2'nci fikrası gereğince başvurucuya bildirilmaktedir.

Yine Kanun'un 8'inci maddesinin 1'inci fikrasına göre SYD vakfi, başvuranların kendilerinin ve başvuruculara karşı nafaka yükümlülügü bulunanların mali ve sosyal durumlarını araştırabilir. Bu araştırma esnasında SYD vakıfları, her türlü bilgi ve belgeye ulaşmaya yetkili kılınmıştır. Bununla amaçlanan gerçe

33 10.07.2018 tarihli ve 30474 sayılı Resmî Gazete.

34 Vakıflar Kanunu'nun 3'üncü maddesine göre vakıf senedi, “Mülga 743 sayll Türk Kanunu Medenisi ile 22/11/2001 tarihli ve 4721 sayılı Türk Medenî Kanunu hükümlerine göre kurulan vakıfların, malvarlığını ve vakıf şartlarını içeren belgeyi" ifade eder.

35 İSBİR, Kevser Begüm: Kamu Tüzel Kişiliği, Turhan Kitabevi, Ankara, 2017, s. 578.

36 Bu aylıklar, 2022 sayılı Kanun'un 1'inci maddesindeki yaşlı aylığı katsayısı ile 2'nci maddesindeki engelli aylıkları katsayılarının, memur aylık katsayısı ile çarpılması ile hesaplanmaktadır. 2021 yılı (Temmuz) ikinci dönem için memur aylık katsayısı, 0,179797 ola rak açıklanmıştır. Hazine ve Maliye Bakanlığının, 07.07.202 tarihli ve 7 Sıra No.lu Mali ve Sosyal Haklara İlişkin Genelgesi, (https://ms.hmb.gov.tr/uploads/2021/07/Mali-VeSosyal-Haklar-Temmuz.pdf, E.T.: 01.10.2021). Bu durumda, yaşl1 aylığ1, (4.387 x 0,179797) 788,77 TL; 18 yaşından büyükler için engelli aylığı, \%70 ve üzeri oranda engelilerde (4860 x 0,179797) 873,81 TL; \%40$\% 69$ oranları arasında engelli olanlarda (3.240 x 0,179797) 582,54 TL; 18 yaşından küçüklerin yakınlarına ödenecek engelli yakını aylığ1 ise (3.240 x 0,179797) 582,54 TL'dir.

37 Yönetmelik'in 5'inci maddesinin 1'inci fikrası şu şekildedir: "2022 sayılı Kanun uyarınca bağlanacak aylıklara ilişkin başvurular, kişilerin adrese dayalı nüfus kayıt sisteminde kayıtlı ikametgâhının bulunduğu Vakfa yapılır.".

38 Yönetmelik'in 5'inci maddesinin 2'nci fikrasına göre "Sosyal inceleme ... Vakıf personeli tarafindan başvuruda bulunanın ikametgâhına ve çevresine gidilmek ve hane ziyaret bilgi formu doldurulmak suretiyle gerçekleştirilir.".

39 "Kanun veya diğer düzenleyici işlemler ya da hukukun genel ilkelerinin yetkili idari otoritenin değerlendirme yetkisinin çerçevesini tanımladığ ve hareket serbestisinin sınırı, kapsamı velveya kullanılmasi yol veya yöntemini net, emredici, yoruma imkân tanımadan, kullanacak makamın değerlendirilmesini mümkün kllmayacak nitelikte ifade edildiği durumlarda bă̆ll yetkiden söz edilir." Bkz. ATAY, Ender Ethem: İdare Hukuku, 6. Bask1, Turhan Kitabevi, Ankara, 2018, s. 519. 
ğe aykırı beyanda bulunanların tespit edilmesi ve haksız olarak aylık alınmasının önlenmesidir. Bu sebeple her türlü inceleme yöntemi kullanılarak ve olabildiğince bilgi ve belgeden yararlanarak başvurucuların muhtaçlık durumları hakkında gerçeğe en yakın duruma ulaşılması hedeflenmiştir. Gerek evrak üzerinden gerek bilgi sistemleri ile gerekse hane ziyareti ile elde ettiği verilere göre ilgilinin muhtaç olmadığını veya başvuruda kullanılan bilgi ve belgelerin gerçeği yansıtmadığının anlaşılması halinde, başvurunun reddine karar verileceği gibi ödenmekte olan aylığın kesilmesi de mümkündür.

Başvurucunun adres değişikliği ve engelli veya yaşlının sağlık raporunun süresinin dolması gibi durumlarda aylığın durdurulması işlemi de yapılabilmektedir ${ }^{40}$. Ancak bunun sonucunda ya eksikler tamamlandığı için aylığın ödenmesine devam edilmekte ya da eksikler tamamlanmadığ 1 için aylık kesme işlemi yapılmaktadır. Bu sebeple aylığın durdurulması işlemi, davaya konu olması açısından ayrı bir başlık altında incelenmemiştir.

Son olarak Yönetmelik'in 10'uncu maddesinin 3'üncü fikrasına göre engelli aylığı ve yaşlı aylığı başvurularının reddi veya bu aylıkların kesilmesi işlemine ilişkin itiraz, ilgili SY D vakfina yapılmaktadır.

$\mathrm{Bu}$ açıklamalar çerçevesinde, 2022 sayılı Kanun kapsamında, SYD vakıfları tarafından ilgililerinin haklarını ihlâl edebilecek iki tür işlem bulunmaktadır: Aylık başvurusunun reddi ve aylığın kesilmesi.

\section{A. Aylık Başvurularının Reddedilmesi İşlemi}

İlgililer tarafindan adrese dayalı kayıt sisteminde ikametgâhlarının bulunduğu yerdeki SYD vakfına aylık başvurusu yapılmasının ardından SYD vakfı tarafından yapılan araştırma sonrasında mütevelli heyet ${ }^{41}$, ilgilinin aylık başvurusunu değerlendirir ve başvurunun kabulüne veya reddine karar verir.

Aylık başvurusunun kabulüne karar verilenlere Aile ve Sosyal Hizmetler Bakanlığı tarafindan aylıkları ödenmeye başlanırken, aylık başvurusunun reddine karar verilenlerin ise ilgili SYD vakfına itiraz etme ve itirazın reddi halinde ise dava açma hakları bulunmaktadır.

2022 say1lı Kanun'un 1'inci maddesinde sayılan;

- Sosyal güvenlik kuruluşlarının herhangi birisinden her ne nam altında olursa olsun bir gelir veya aylık hakkından yararlananlara,

- Uzun vadeli sigorta kolları açısından zorunlu olarak sigortalı olunması gereken bir işte çalışanlara,

- Nafaka bağlanmış veya nafaka bağlanması mümkün olanlara,

- 24/5/1983 tarihli ve 2828 sayılı Sosyal Hizmetler Kanunu hükümlerine göre harçlık ödenenlere,

2022 sayılı Kanun kapsamında aylık bağlanamamakta olup bu şartları taşımayan kişiler tarafından yapılan başvurular reddedilmektedir. Bunun yanında, başvurucunun Türk vatandaşı olması gerekmektedir. Bu şartları sağlayanlar, muhtaçlık yönünden incelenmektedir. Başvurucunun kendisine ve eşine ait her türlü gelirler toplamı esas alınmak suretiyle, kişi başına düşen ortalama aylık gelir tutarı asgari ücretin aylık net tutarının 1/3'ünden fazla olanlar ile aynı tutardan fazla gelir sağlaması mümkün olan kimseler muhtaç kabul edilememekte ve kendilerine aylık bağlanamamaktadır ${ }^{42}$. Bu aşamada, muhtaç olmadığı tespit edilenlerin aylık başvuruları reddedilmektedir.

Aylığın türüne göre de şartlar bulunmaktadır. Örneğin, 2022 sayılı Kanun'un 1'inci maddesi uya rınca yaşlı1ık aylığı bağlanacaklarda, başvurucunun 65 yaşını doldurmuş olması gerekmektedir. 65 yaş hesabında, yaş düzeltmelerin de dikkate alınmayacağı 2022 sayılı Kanun'da açıkça belirtilmiştir.

40 Yönetmelik'in 11 'inci maddesinin 1'inci fikrasında göre, yaşlı aylığı ve engelli aylıkları, adres değişikliği ile süreli sağlık kurulu raporunun süresinin dolması hallerinde geçici olarak durdurulur.

41 Vakıf mütevelli heyeti, vakfın karar organı olduğu için, bu karara vakfın kararı denilmesinde bir çekince bulunmamaktadır.

42 Anayasa Mahkemesi, engelli veya yaşlının gelirinin yanında, aynı hanede yaşayan diğer kişilerin de gelirinin esas alınarak, hanedeki ortalama gelirin hesaplanması uygulamasına ilişkin 2022 sayılı Kanun'un 2'nci maddesinin Anayasa'ya aykırı olmadığına karar vermiş$\operatorname{tir}$ (AYM, T. 12.11.2020, E. 2020/13, K. 2020/68). 
2022 sayılı Kanun'un 2'nci maddesinde, engelli aylığı almak için başvuru şartı olarak, hak sahibinin sağlık kurulu raporu ile en az $\% 40$ oranında $^{43}$ engelli olduğunun kanıtlanmış olması şartı yer almaktadır. Ayrıca, engelli 18 yaşından büyük ise bir şart daha yer almakta olup bu şart, talebine rağmen Türkiye İş Kurumu tarafından işe yerleştirilememiş olmaktır.

Bu çerçevede, 2022 sayılı Kanun'da sayılan aylık başvurusu şartlarını taşımayanların aylık başvur ruları SYD vakıfları tarafindan reddedilmektedir.

\section{B. Aylıkların Kesilmesi İşlemi}

2022 sayılı Kanun'un 8'inci maddesinin 1'inci fikrasına göre SYD vakıfları, gerektiğinde aylık alanlar hakkında inceleme yapmaya yetkilidir. Bunun yanında, Yönetmelik'in 6'ncı maddesinin 3'üncü fikrasına göre aylık almaya hak kazanan kişilerin sosyal incelemeleri her yıl yenilenmektedir.

Aylık almakta olanlar hakkında yapılan incelemeler sonucunda, ilgililer tarafından aylık bağlama sürecini etkileyebilecek hataların veya eksikliklerin giderilmemesi veya aylığa hak kazanmaya esas sağlık kurulu raporu veya diğer belgelerin gerçeğine aykırı olarak düzenlendiğinin anlaşılması halinde aylık kesme işlemi yapılmaktadır. Bunun yanında, daha önce açıklanan aylık bağlama şartlarının kaybedildiğinin tespiti halinde de yine aylık kesme işlemi yapılmaktadır. Bu kararlara karşı da SYD vakıflarına itiraz edilmesi ve itirazın reddi halinde dava açılması söz konusudur.

Aylık başvurusunun reddi işlemi sadece SYD vakıfları tarafindan tesis edilebilirken aylığın kesilmesi işlemi hem SYD vakıfları hem de Aile ve Sosyal Hizmetler Bakanlığı tarafından yapılabilmektedir. Özellikle 2022 sayılı Kanun kapsamında, aylık alanların Sosyal Güvenlik Kurumu'nda kaydı olduğunun tespit edilmesi halinde aylıklar, Bakanlık tarafından doğrudan kesilmektedir ${ }^{44}$.

2022 sayılı Kanun'un 8'inci maddesinin 2'nci fikrasında “'Aylı bağlama işlemi sırasında veya aylık bağlandıktan sonra yapılacak incelemeler sonucunda, aylık bağlama kararını etkileyebilecek yanlışlık veya eksikliklerin tespit edilmesi hâlinde, bu durum ilgisine göre Vakfflara, aylık bağlanana veya bağlanacak olana ve gerektiğinde ilgili idarelere Vaklf veya Bakanlık tarafindan bildirilir. Aylık bă̆lanmış veya bağlanacak olanlara yapılacak bildirimlerin iadeli taahhütlü posta ile gönderilmesi esastır. Aylık bağlanmış olanlarla ilgili eksikliklerin veya yanlışlıkların giderilmemesi hâlinde, tebligat tarihinden itibaren ü̧̧ aylı sürenin sona erdiği tarihin içinde bulunduğu ödeme döneminin sonunda aylık kesme veya düzeltme işlemi yapılır ve fazla ödenen tutarlar geri alınır." denilerek özellikle ayl1ğın kesilmesi işleminde Bakanlığın ve SYD vakıflarının yetkilerinin bulunduğu açıkça belirtilmiştir.

\section{SOSYAL YARDIMLAŞMA VE DAYANIŞMA VAKIFLARININ AYLIK BAŞVURUSUNUN REDDİ VE AYLIĞIN KESİLMESI İŞLEMLERİNIN HUKUKI NITTELENDỈRILMESI}

Doktrindeki ve yargı kararlarındaki idari işlem tanımlarının ortak noktaları esas alındığında idari işlem; kişilerin kendilerini, haklarını ve yükümlülüklerini etkileyen, kamu gücü kullanılarak yapılan tek yanlı irade açıklamalarıdır. İdari işlem, idare tarafından yapılabilir. Yasama ve yargı fonksiyonu ile ilgili olmayıp idare fonksiyonuna ilişkin olarak yasama veya yargı organlarınca da idari işlem tesis edilebilir. İdare adına hareket eden özel hukuk kişileri de idare kapsamında değerlendirilmektedir ${ }^{45}$.

Bu tanımdan çıkan sonuçlardan birisi de özel hukuk kişilerince de idari işlem tesis edilmesinin mümkün olmasıdır. Kamu hizmetlerinin sayısının ve çeşitliliğinin artması ile özel hukuk kişilerinin de

43 Yönetmelik'in 2'nci maddesine göre engelli aylı̆̆ına hak kazanılması için, engellinin, en az \%40 oranında engelli olduğunun kanıtlanması gerekmektedir. Buna ek olarak, engelli aylıkları \%40 ila \%69 arası engelli olanlara farklı tutarda; \%70 ve üzeri oranda engelli olanlara farklı tutarda ödenmektedir. Ayrıca, bu Yönetmelik'in 5'inci maddesine göre engellinin 18 yaşından küçük olması halinde ödenen aylığa "engelli yakını aylı̆̆ı" denilmekte olup bu aylık, engellinin veli ya da vasisine ödenmektedir.

44 Aile ve Sosyal Hizmetler Bakanlığı, Sosyal Yardımlar Genel Müdürlüğü, Sıkça Sorulan Sorular, 2022 aylıkları, 75'inci soru (https://www.aile.gov.tr/sss/sosyal-yardimlar-genel-mudurlugu/2022-kanun-kapsaminda-yurutulen-ayliklar//, E.T.: 10.11.2021).

45 AKYILMAZ, Bahtiyar / SEZGINER, Murat / KAYA, Cemil: Türk İdare Hukuku, Yenilenmiş 9. Baskı, Savaş Yayınevi, Ankara, 2018, (Türk İdare Hukuku), s. 302. 
kamu gücü kullanmak suretiyle idari işlem tesis edebilmelerine yasalar ile imkân verilmiştir. Bu özel hukuk kişileri, kamu gücü ayrıcalıklarından yararlanarak tek yanlı irade açıklamaları yapabilmektedir$l^{4}{ }^{46}$. Dolayısıyla idari işlemlerin tesisinde idari makam kavramı, kamu kurum ve kuruluşları ile mevzuat ile yetkilendirilmiş özel hukuk tüzel kişilerini kapsamaktadır ${ }^{47}$.

$\mathrm{Bu}$ çerçevede değerlendirme yapıldığında, özel hukuk tüzel kişisi olan SYD vakıfları tarafından 2022 sayılı Kanun uyarınca tesis edilen, ilgililerin hukuki durumlarını etkileyen tek yanlı irade açıklamaları olan aylık başvurusunun reddi ve aylığın kesilmesi işlemleri idari işlemlerdir.

Danıştayın "İdari makamların kamu gücü ve kamu kudreti kullanarak idare işlevine ilişskin olarak tesis ettikleri, muhatapları yönünden çeşitli hak ve/veya yükümlülükler doğuran tek yanlı irade açıklamalarıdır" şeklindeki tanımını değerlendirdiğimizde de idari işlemin unsurları; "idari makamlarca yapılmış olma", "tek yanlı olma" ve "icrailik niteliğini taşıma"dır ${ }^{48}$. Bu tanımda yer alan "idari makamlarca yapılmış olma" şartının idari yargı yerlerinin, özel hukuk tüzel kişilerinin idari işlem tesis edemeyeceği yönündeki hatalı kararlarına neden olduğu görülmektedir. Buna karşın idari makam kavramı, sadece idari teşkilatı kasteden bir ifade olmayıp idare işlevine ilişkin eylem ve işlemlerde bulunan kamu idareleri yanında özel hukuk tüzel kişilerini de kapsamaktadır ${ }^{49}$. Bu sebeple, yasanın verdiği yetkiyle hareket eden özel hukuk tüzel kişilerince idari işlem tesis edilebileceği idare hukukunda kabul edilmektedir. Bu şekilde idari işlemtesis edebilen özel hukuk tüzel kişileri idari makam kavramına dâhildir ${ }^{50}$. Bu bağlamda, SYD vakıflarının da idare işlevine ilişkin işlemlerinin idari işlem olarak kabul edilmesi gerekmektedir ${ }^{51}$.

Günümüzde kamu gücü kavramı, "emredici güç” anlamında kullanılmamakta; idari makamlara özel hukukta öngörülmeyen ayrıcalıkların verilmesi halinde, kamu gücünün kullandığı kabul edilmektedir. Bu bağlamda, SYD vakıflarının aylıklarla ilgili işlemlerinin kamu gücü kullanma açısından de ğerlendirilmesi halinde de icrai işlem yapabilme ayrıcalığı kapsamında işlem tesis edebilen SYD va kıflarının kamu gücü kullandığı söylenebilir ve kamu gücü kullanılması sebebiyle bu işlemlerin idare hukuku alanında olduğu kabul edilebilit ${ }^{52}$.

İptal davasının konusunu oluşturması açısından ise idari işlem, idarenin idare hukuku alanında kamu gücü kullanarak yaptıkları tek yanlı irade açıklamalarıdır. Bu tanıma göre idari işlem, kişilerin menfaatine uygun da olabilmektedir, kişilerin menfaatini ihlâl edici nitelikte de olabilmektedir ${ }^{53}$. Bu kapsamda, SYD vakıflarının aylık başvurusunun reddi ve aylığın kesilmesi işlemleri, idari yargıdaki iptal davasına konu olabilecek menfaati ihlâl eden idari işlemlerdir.

\section{SOSYAL YARDIMLAŞMA VE DAYANIŞMA VAKIFLARININ, AYLIK BAŞVURUSUNUN REDDI VE AYLIĞIN KESILMESI ISSLEMLERININ İPTALİ DAVALARINDA GÖREVLİ YARGI YERI}

2577 sayılı İdari Yargılama Usûlü Kanunu'nun (IYYK) ${ }^{54}$ 2'nci maddesine göre, iptal davalarının menfaatleri ihlâl edilenler tarafından açılabileceği dikkate alındığında, SYD vakıfları tarafından 2022

46 CANDAN, Turgut: Açıklamalı İdari Yargılama Usûlü Kanunu, 5. Baskı, Adalet Yayınevi, Ankara, 2012, s. 73; YILMAZ, Dilşat: İdari İşlemin İcrailik Özelliği, Astana Yayınları, Ankara, 2014, (Ícrailik Özelliği $),$ s. 18.

47 ATAY, s. 426.

48 Danıştay, IDDK., T. 18.02.2016, E. 2014/5338, K. 2016/349.

49 DEVOLVÉ, Pierre: L'Acte Administratif, Sirey, Paris, 1983, s. 19'dan aktaran ERKUT, Celal; İptal Davasının Konusunu Oluşturma Bakımından İdari İșlemin Kimliği, Tıpkı Basım, Danıștay Matbaası, 2015, s. 76.

50 ATAY, s. 418.

51 Danıştay, 12. D., T. 13.03.2014, E. 2013/6822, K. 2014/1612 say1lı kararında, "Bilindiği üzere, idari makamlar dışındaki organlar tarafindan yapılan bazı islemlerin idari islemler olarak kabul edilmeleri, idare islevinin yapısal anlamda idarenin disında kalan organlarca da yürütülebilen bir faaliyet olmasından kaynaklanmaktadır. Bu bağlamda, bu faaliyetin yürütülmesini sağlayan işlemlerin gördükleri işlev açısından idari işlemler olarak nitelendirilmesinde işlevsel ölçütten yararlanılması zorunludur." denilmiş ve sosyal yardımlaşma ve dayanışma vakıfları tarafından tesis edilen bir idari işlemin, iptal davasına konu olması gerektiğini "idare işlevi" kavramı ile açıklamaya çalışmış fakat Danıştay, SYD vakıflarını bu kararda da idari makam olarak kabul etmemiştir.

52 GÖZLER, Kemal / KAPLAN, Gürsel: İdare Hukuku Dersleri, 18. Bask1, Ekin Kitabevi, Bursa, 2016, s. 50.

53 AKYILMAZ / SEZGINER / KAYA, Türk İdare Hukuku, s. 300.

5420.01 .1982 tarihli ve 17580 sayılı Resmî Gazete. 
sayılı Kanun kapsamında kişilerin menfaatlerini ihlâl eden iki işlem olduğu ve bu işlemlerin aylık başvurusunun reddi işlemi ve aylık almakta olanların aylığının kesilmesi işlemi olduğu anlaşılmakta dır. Bu işlemlere karşı yapılacak itiraz da Yönetmelik'in 10'uncu maddesinin 3'üncü fikrasına göre yine aynı SYD vakfı tarafından değerlendirilecektir. İtirazdan da sonuç alınamaması halinde uyuşmazlığa neden olan işlemin iptali için dava açılması gerekmektedir.

Danıştay, özel hukuk tüzel kişiliği bulunan SYD vakıfları tarafından tesis edilen bu işlemlerin idari işlem mahiyetinde olmadığı ve bu uyuşmazlığın özel hukuk hükümleri çerçevesinde çözümlenmesi gerektiği yönünde karar vermektedir ${ }^{55}$. Danıştayın, bir idari işlemin ancak bir idari makam tarafından tesis edileceği yönündeki değerlendirmesinin eksik olduğu anlaşılmaktadır.

Önceki bölümlerde açıklandığı üzere idari makam kavramı, sadece idari teşkilata özgü olmayıp idare işlevine ilişkin faaliyet ve işlemlerde bulunan kamu kurumları ile özel hukuk tüzel kişilerini de kapsamaktadır ve yasalarla yetkilendirilmiş özel hukuk tüzel kişileri de idari işlem tesis edebilmekte$\mathrm{dir}^{56}$. Dolayısıyla, idari işlemin tüm unsurlarını taşınan ve SYD vakıfları tarafından tesis edilen aylık başvurusunun reddi ve aylığın kesilmesi işlemlerine karşı açılan davalarda görevli yargı yeri idari yargıdır. Çünkü bu işlemler 2022 sayılı Kanun'a dayanılarak, başka bir ifade ile kamu gücü kullanılarak, kamu hukuku alanında tesis edilmektedir. Başvurunun reddi ve aylığın kesilmesi işlemleri tek yanlıdır ve icrai niteliktedir. Bunun yanında, bu uyuşmazlıkların, 2022 sayılı Kanun ve Yönetmelik çerçevesinde çözümlenmesi gerekmektedir.

2022 sayılı Kanun uyarınca bağlanan aylığın kesilmesine ilişkin Vezirköprü SYD Vakfinın kara rının iptali istemiyle açılan davalarda, Samsun 2. İdare Mahkemesi ve Vezirköprü 2. Asliye Hukuk Mahkemesi tarafından verilen görevsizlik kararları üzerine uyuşmazlık UYM'ye intikal etmiştir. UYM, bu uyuşmazlıkta “... davaya konu edilen işlemlerin, 3294 sayıl yasanın 7. maddesi kapsamında vakıf mütevelli heyeti kararl ile yapıldiğl, 3294 sayıl y asa gereğince söz konusu vakıfların Medeni Kanun hükümlerine tabi olarak kurulup faaliyette bulunmalarının öngörülmüş olması nedeni ile dava konusu işlemin kamu gücü kullanılmak suretiyle tesis edildiğinin kabulünün mümkün bulunmadiğl sonucuna varılmakla; davanın görüm ve çözümünde adli yargı yerinin görevli olduğuna" karar vermiştir ${ }^{57}$. UYM'nin bu kararındaki değerlendirme de hatalıdır. Kamu gücü kullanımı, somut bir olayda, doğrudan hukukî sonuca yönelik ve muhatabının hukuki durumunu etkileyen tek taraflı bir eylemi ifade etmektedir ${ }^{58}$. Diğer bir ifade ile idari işlemin icrailiği, bir işlemin başka bir işleme veya onaya ihtiyaç duymaksızın ilgilileri hakkında hukuki sonuçlar doğurmasıdır ve icrai işlem yapanların kamu gücü kullandığı kabul edilmektedir ${ }^{59}$.

SYD vakıfları, 2022 sayılı Kanun kapsamında tesis ettikleri işlemlerde kamu gücünü kullanmakta olup bu işlemler neticesinde ilgililere aylık bağlanmamakta veya ilgililerin aldıkları aylıklar kesilmekte olup bu işlemler, özel hukuk usullerine göre yapılmamaktadır ${ }^{60}$. Bu nedenle, SYD vakıflarının 2022 sayılı Kanun kapsamında yaptıkları işlemlerde kamu gücü kullanıldığı açıktır. Diğer bir ifade ile idari makamların her işlemi idari yargının görev alanına girmediği gibi, bir özel hukuk tüzel kişisi olan SYD vakıflarının da kamu hukuku alanındaki, 2022 sayılı Kanun kapsamındaki işlemleri gibi, bazı işlemleri idari yargının görev alanına girmektedir.

İdari işlemlerden doğan uyuşmazlıklarda kural olarak görevli yargı yeri idari yargıdır. Ancak kanun ile bir konuda tesis edilen işlemlerden kaynaklanan uyuşmazlıkların çözüm yeri adli yargıya bıra

55 Danıştay, 10. D., T. 21/09/2017, E. 2017/1801, K. 2017/3706; Danıştay, 10. D., T. 14/05/2018, E. 2018/2151, K. 2018/1776.

UYM, T. 08.07.2019, E. 2019/279, K. 2019/422.

58 AKYILMAZ / SEZGINER / KAYA, Türk İdare Hukuku, s. 309.

59 ATAY, s. 429; YILMAZ, İcrailik Özelliği, s. 31.

60 SANCAKDAR, Oğuz / US, Ender / KASAPOĞLU TURHAN, Mine / ÖNÜT, Lale Burcu: İdare Hukuku Teorik Çalışma Kitabı, 5. Baskı, Seçkin Yayıncılık, Ankara, 2015, s. 336. 
k1labilir. Bu durum istisnaidir ${ }^{61} .2022$ sayılı Kanun kapsamındaki aylığın kesilmesi ve aylık başvurut sunun reddi işlemlerinin adli yargının denetimine bırakılmasına ilişkin yasal bir düzenleme bulunma maktadır. Hatta 18.06.2014 tarihli ve 6545 sayılı Kanun ile değişiklik yapılmadan önceki halinde IYUK'un 45'inci maddesinin 1'inci fikrasının (g) bendinde, 2022 sayılı Kanun'la ilgili uygulamalardan doğan uyuşmazlıkların idari yargının görev alanında olduğu belirtilmektedir ${ }^{62}$. Buna karşın, Uyuşmazlık Mahkemesinin son yıllardaki kararları ile uyuşmazlığın çözümünün adli yargıya bırakılması, SYD vakıflarınca tesis edilen idari işlemlerin nasıl iptal edileceği sorununu da beraberinde ge tirmektedir. Çünkü adli yargıda, idari yargıdaki gibi bir iptal davası bulunmamaktadır.

Talep edilen hukuki korumaya göre sınıflandırılması halinde, adli yargıdaki hukuk dava türlerini tespit, eda ve inşai davalar olmak üzere üçe ayırabiliriz. Bu dava türlerinde mahkemelerce verilen kararlar, eda davalarında ve tespit davalarında açıklayıcı; inşai davalarda ise yaratıcı niteliktedir ${ }^{63}$. 6100 sayılı Hukuk Muhakemeleri Kanunu'nun (HMK) ${ }^{64}$ 2'nci kısım 1'inci bölümünde bu davalar sayılmıştır. HMK'nın 105'inci maddesinde, eda davası ile davalının bir şeyi vermeye, bir şeyi yapma ya veya bir şeyi yapmamaya mahkûm edilmesi talep edileceği belirtilmiştir. HMK'nın 106'ncı maddesinde, tespit davası ile bir hakkın veya hukuki ilişkinin varlığının veya yokluğunun, bir belgenin sahte olup olmadığının belirlenmesinin talep edileceği ifade edilmiştir. HMK'nın 108'inci maddesinde, inşaî dava ile yeni bir hukuki durum yaratılmasının, hâlihazırdaki hukuki durumun içeriğinin değiştirilme sinin veya ortadan kaldırılmasının talep edilebileceği düzenlenmiştir.

Eda davası sonucunda verilen kararı davalı yerine getirmezse ilamlı icra yoluyla kararın yerine getirilmesinin sağlanması icap etmektedir. Tespit davası ile davalı bir şey yapmaya zorlanamamaktadır. İnşaî davalar ise ancak HMK' da belirtilen durumlarda açılabilmektedir ${ }^{65}$. Bu davalar ile SY D va kıfları tarafından tesis edilen aylık başvurusunun reddi veya aylığın kesilmesi işlemlerinin iptal edilemeyeceği ortadadır. Çünkü bu dava türleri, SYD vakfının kararının iptal edilmesi ve SYD vakfı tara fından yeniden bir karar verilmesini sağlayacak nitelikte kararlar verilmesine imkân vermemektedir. Hukuk mahkemesi kararının SYD vakfının kararı yerine geçmeyeceği ve yargının, SYD vakfına işlem tesis etmesi veya tesis ettiği işlemi iptal etmesi yönünde emir veremeyeceği göz önünde bulundurulduğunda, aylığın kesilmesi ve aylık başvurusunun reddi işlemlerinin hukuk mahkemesindeki yargılamaya konu olması hukuki olarak elverişli değildir.

Vakıflara özgü davalar açısından görevli yargı yeri konusunu ele aldığımızda ise vakıf davalarında vakfın kuruluşu, tescili, denetimi, yönetimim değiştirilmesi, vakfın amacının değiştirilmesi, vakfin mallarının değiştirilmesi ve vakfin sona erdirilmesi konularında asliye hukuk mahkemeleri görevlidir ${ }^{66}$. Bunun yanında, vakıflara ait taşınmazların kiralanması ile ilgili uyuşmazlıklarda sulh hukuk mahkemeleri görevlidirr7. Buna göre, SYD vakfı tarafından tesis edilen aylık başvurusunun reddi işlemine veya aylığın kesilmesi işlemine karşı açılacak davalarda adli yargının görevli olduğuna ilişkin

61 Danıştay, IDDK, T. 01.12.2016, E. 2016/834, K. 2016/3261.

62 IYYUK'un itiraz başlıklı 45'inci maddesinin, 18.06.2014 tarihli 6545 sayılı Kanun'un 19'uncu maddesiyle değiștirilmeden önceki hali şu şekildedir: "İdare ve vergi mahkemelerinin; ... g) 1/7/1976 tarihli ve 2022 sayılı 65 Yaşını Doldurmuş Muhtaç, Güçsüz ve Kimsesiz Türk Vatandaşlarına Aylık Bağlanması Hakkında Kanun ile 29/5/1986 tarihli ve 3294 sayılı Sosyal Yardımlaşma ve Dayanışmayı Teşvik Kanunu gereğince kamu kurum ve kuruluşları tarafindan sosyal yardım amactyla bağlanan aylık ve yapılan sosyal yardımlarla ilgili uygulamalardan, ... kaynaklanan uyuşmazllklarla ilgili olarak verdikleri nihai kararlar ile tek hakimle verilen nihai kararlara, başka kanunlarda aksine hüküm bulunsa dahi mahkemelerin bulunduğu yargı çevresindeki bölge idare mahkemesine itiraz edilebilir." (www.corpus.comtr, E.T.: 18.12.2020).

63 PEKCANITEZ, Hakan / ATALAY, Oğuz / ÖZEKES, Muhammet: Medeni Usûl Hukuku Ders Kitabl, 8. Baskı, On İki Levha Yayıncılık, İstanbul, 2020, s. 214.

64 04.02.2011 tarihli ve 27836 sayılı Resmî Gazete.

65 PEKCANITEZ / ATALAY / ÖZEKES, s. 214-218.

66 UYM, T. 08.07.2019, E. 2019/279, K. 2019/422 sayılı kararı sonrasında, Ankara 6. Asliye Hukuk Mahkemesi, T. 26.05.2021, E. 2021/426 sayılı kararı ile Çankaya Sosyal Yardımlaşma ve Dayanışma Vakfı mütevelli heyetinin engelli aylığı başvurusunun reddi kara rının tedbiren durdurulmasına karar vermiştir. Kanunlarda bu yönde düzenleme olmamasına rağmen, Ankara 6. Asliye Hukuk Mahke mesi, kendini engelli yardımı konusunda, diğer bir ifade ile esas hakkında, görevli ve yetkili olarak kabul ederek HMK'nın 389'uncu ve 390'ıncı maddeleri uyarınca ihtiyati tedbir kararı vermiștir.

67

$\mathrm{EM}, \mathrm{s} .42$. 
bir kanun hükmü bulunmamaktadır. Hâlbuki idari işlemlere ilişkin uyuşmazlıkların çözüm yeri ancak kanunla adli yargıya birakılabilir ${ }^{68}$.

İdarenin, idare hukuku kuralları çerçevesinde yaptı̆̆ işlem ve eylemlerden doğan davalar idari davalardır ${ }^{69}$. IYYUK'un “İdari Dava Türleri ve İdari Yarg1 Yetkisinin Sınırı” başlıklı 2'nci maddesinde idari dava türleri sayılmıştır. Buna göre iki tür idari dava bulunmakta olup bunlar iptal davası ve tam yargı davasıdır. Üçüncü tür idari dava olarak IYYUK'ta idari sözleşmelerden dolayı taraflar arasında çıkan uyuşmazlıklara ilişkin davalar sayılsa da bu maddedeki "tahkim yolu öngörülen imtiyaz şartlaşma ve sözleşmelerinden doğan uyuşmazlıklar hariç, kamu hizmetlerinden birinin yürütülmesi için yapılan her türlü idari sözleşmelerden dolayı taraflar arasında çıkan uyuşmazlıklara iliş̧kin davalar" şeklindeki tanım, bir dava türünü belirtmemektedir. Burada uyuşmazlığın kaynağını tanımlamaktadır. Bu nedenleidari davaları, iptal ve tam yargı davaları olarak iki çeşit olarak kabul edilmektedir ${ }^{70}$.

IYYUK'a göre tam yargı davası, idari eylem ve işlemlerden dolayı kişisel hakları doğrudan muhtel olanlar tarafından açılan davalardır. Tam yargı davaları, idarenin bir işlemi veya eylemi ile zarara uğrayan kişilerce idari yargıda, idareye karşı açılan tazminat davaları olarak tanımlanabilir. Tam yargı davalarında bir hakkın geri verilmesine ilişkin talepler söz konusu olsa da uygulamada, genel olarak, tazminat talepleri tamyargı davalarına konu olmaktadır ${ }^{71}$.

2577 sayılı Kanun'da “idarî işlemler hakkında yetki, şekil, sebep, konu ve maksat yönlerinden biri ile hukuka aykırı olduklarından dolayı iptalleri için menfaatleri ihlâl edilenler tarafindan açılan davalar..." olarak tanımlanan iptal davaları ile bir idari işlemin hukuka aykırılığının tespit edilerek idari yargı makamlarınca iptal edilmesi sağlanmaktadır ${ }^{72}$. Bu dava tünü ile idarenin hukuka uygun davranması da teminat altına alınmaktadır ${ }^{73}$.

SYD vakıfları tarafından tesis edilen aylık başvurusunun reddi ve aylığın kesilmesi işlemlerinin birer idari işlem olduğu ve bu işlemler ile hak sahiplerinin menfaatlerinin ihlâl edildiği göz önünde bulundurulduğunda, anılan işlemlerin idari yargıdaki iptal davasına konu olmaları gerektiği sonucuna ulaşılmaktadır.

Aylık başvurusunun reddi ve aylığın kesilmesi nedeniyle ortaya çıkan uyuşmazlık özel hukuk kurallarına göre çözümlenebiliyorsa adli yargı, idare hukuku kurallarına göre çözümlenebiliyorsa idari yarg1 görevlidir ${ }^{74}$.

IYUK'un 28'inci maddesinin 1'inci fikrasındaki "Danıştay, bölge idare mahkemeleri, idare ve vergi mahkemelerinin esasa ve yürütmenin durdurulmasına ilişkin kararlarının icaplarına göre idare, gecikmeksizin işlem tesis etmeye veya eylemde bulunmaya mecburdur. Bu süre hiçbir şekilde kararın idareye tebliğinden başlayarak otuz günü geçemez." hükmü uyarınca ilgili SYD vakfı, gecikmeksizin davacı hakkında idare mahkemesi kararına uygun olarak yeniden işlem tesis etmek zorunda kalacaktır. Adli yargı yerleri tarafindan verilen kararlar için bu tür ayrıntılı bir düzenleme bulunmamaktadır. Anayasa'nın 138'inci maddesi gereğince her türlü mahkeme kararının idarelerin yerine getirmesi zorunluluk olsa da çoğu zaman iptal edilen işlemin yerine yenisinin yapılmasının gerekli olması ve bunun yapilmaması sebebiyle davacının talebinin tam olarak yerine getirilmemesi söz konusudur ${ }^{75}$. IYUK'taki bu düzenleme ile davacının hakları daha sıkı korunmuştur.

\footnotetext{
68 SANCAKDAR / US / KASAPOĞLU TURHAN / ÖNÜT, s. 366

69 TAN, Turgut: İdare Hukuku, 2. Bask1, Turhan Kitabevi, Ankara, 2013, s. 743.

70 AKYILMAZ, Bahtiyar / SEZGİNER, Murat / KAYA, Cemil: Türk İdari Yargılama Hukuku, Savaş Yayınevi, Ankara, 2018, (Türk İdari Yargllama Hukuku), s. 170; CANDAN, s. 207.

71 CANDAN, s. 150

72 GÖZLER / KAPLAN, s. 827.

73 TAN, s. 996.

74 AUBY, Hean-Marie / DRAGO, Roland: Traité de Contentieux Administratif, LGDJ, 2. Cilt, 6. Bask1, 1975, s. 333-334'ten aktaran GÖZLER / KAPLAN, s. 820.

75 CANDAN, s. 710.
} 
IYYK'un 20'nci maddesinin 1'inci fikrasında "Danıştay, bölge idare mahkemeleri ile idare ve vergi mahkemeleri, bakmakta oldukları davalara ait her türlü incelemeyi kendiliğinden yapar." denilerek idari davalarda re'sen araştırma ilkesinin uygulanacağ i ifade edilmiştir. Buna ek olarak, IYUK'un 16'ncı maddesinin 5'inci fikrasındaki "Davalara ilişkin işlem dosyalarının asl veya onaylı örneği idarenin savunması ile birlikte, Danıştay veya ilgili mahkeme başkanlı̆̆ına gönderilir." hükmü nedeniyle vakıf tarafından mahkemeye konu ile ilgili tüm bilgi ve belgeler gönderilecektir. Bu şekilde, davaya konu uyuşmazlıkla ilgili tarafların mahkemeye bilgi ve belge getirmemesi veya eksik getirmesinden kaynaklanan sorunlar, resen araştırma ilkesinin geçerli olmadığı adli yargı davalarına göre çok daha az yaşanmaktadır ${ }^{76}$.

2022 sayılı Kanun'dan kaynaklanan uyuşmazlıklarının adli yargıda görülecek olmasının bir diğer sakıncası ise adli yargının talep ile bağlı olması ve tarafların mahkemeye süresi içinde sunacağı delillere göre karar vermek zorunda olmasıdır. Hukuk yargılamasındaki teksif ilkesine göre taraflar; iddia, savunma ve delillerini belirli bir süre içerisinde sunabilir. Bu sürenin geçmesinden sonra sunulan dava malzemeleri mahkeme tarafindan dikkate alınamaz. Taraflarca getirilme ilkesinin sonucu olarak da adli yargı hâkimi, tarafların getirdiği vakalar dışında vakaları ele alamaz, getirilmeyen vakaları hatırla tamaz, kişisel bilgisini kullanamaz, tarafların getirdiği deliller dışında delile dayanarak karar vere$\mathrm{mez}^{77}$.

Adli yargıda re'sen araştırma ilkesi de sınırlı olarak kullanılmaktadır. Ancak HMK'nın 385'inci maddesinin 2'nci fikrası uyarınca hukuk davalarında re'sen araştırma ilkesi, genel olarak çekişmesiz yargıda uygulanmaktadır ${ }^{78}$. Buna karşın, 2022 sayılı Kanun kapsamında aylık bağlanan kişilerin muhtaç ve yaşlı vatandaşlar ile muhtaç ve engelli vatandaşlar olduğu dikkate alındığında, delillerin taraflarca getirilmesi ilkesi ${ }^{79}$ ile teksif ilkesinin egemen olduğu adli yargı yerine, re'sen araştırma ilkesinin uygulandığı idari yargıda davanın görülmesi, uyuşmazlığın hakkaniyete uygun bir biçimde çözümlenmesi için daha elverişlidir.

Vakıflar tarafından tesis edilen işlemler hakkındaki Uyuşmazlık Mahkemesinin ve Danıştayın eski tarihli kararları daha isabetlidir. Uyuşmazlık Mahkemesi, tesis edilen idari işlem açısından yapılan değerlendirmede Adalet Teşkilatını Güçlendirme Vakfını idari makam kavramı içinde kabul ederek vakfın davalı idare olmasına karar vermiştir" ${ }^{80}$ Danıştay 5. Dairesi "Adalet Teşkilatını Güçlendirme Vakfi'nın Medeni Kanun hükümlerine göre kurulmuş bir özel hukuk tüzel kişisi olması, tümü merkezi idarenin üst düzey kamu görevlilerinden oluşan Vakıf Yönetim Kurulunca idari usul ve esaslara göre tesis edilen işlemin idari niteliğini ortadan kaldırmaz." şeklindeki kararı ile Uyuşmazlık Mahkemesinin kararı doğrultusunda karar vermiştir ${ }^{81}$. Bu kararda, Adalet Teşkilatını Güçlendirme Vakfının idari işlem tesis etme yetkisi verilen bir özel hukuk tüzel kişisi olduğu belirtilerek, idari işlem tesis edebilmesi nedeniyle davalı idare oluğu belirtilmiştir.

Bir diğer dava ise Türk Diyanet Vakfı ile ilgidir. Bu davada Danıştay 5. Dairesi “Türkiye Diyanet Vakfinın Medeni Kanun hükümlerine göre kurulmuş bir özel hukuk tüzel kişisi olmasl, tümü merkezi idarenin üst düzey kamu görevlilerinden oluşan Vakıf Yönetim Kurulunca idari usûl ve esaslara göre tesis edilen işlemin idari niteliğini ortadan kaldırmaz." şeklinde karar vermiştir ${ }^{82}$. Özetle, Uyuşmazlık Mahkemesinin ve Danıştayın önceki kararlarının daha isabetli olduğu anlaşılmaktadır.

\footnotetext{
76 AKYILMAZ / SEZGINER / KAYA: Türk İdari Yargılama Hukuku, s. 31.

77 PEKCANITEZ / ATALAY / ÖZEKES, s. 186-187.

78 TANRIVER, Süha: Medeni Usûl Hukuku, Cilt 1, 2. Baskı, Yetkin Yayınları, Ankara, 2018, s. 373.

79 HMK'nın, “Taraflarca Getirilme İlkesi” başlıklı 25'inci maddesinde “(1) Kanunda öngörülen istisnalar dişında, hâkim, iki taraftan birinin söylemediği şeyi veya vakıaları kendiliğinden dikkate alamaz ve onları hatırlatabilecek davranışlarda dahi bulunamaz. (2) Kanunla belirtilen durumlar dışında, hâkim, kendiliğinden delil toplayamaz." denilmektedir.

80 UYM, T. 03.05.1999, E. 1999/1, K. 1999/11.

1 Danıştay, 5.D., T. 17.05.2000, E. 2000/476, K. 2000/1516.

82 Danıştay, 5.D., T. 01.04.2003, E. 2000/624, K. 2003/1085.
} 
Konuyu yine bir Danıştay kararı ile özetleyecek olursak bir tüzel kişinin özel hukuk hükümlerine tabi olduğunun hükme bağlanmış olması, bu tüzel kişi tarafindan tesis edilen işlemlerin idari işlem olma niteliğini ortadan kaldırmaz ${ }^{83}$.

\section{SOSYAL YARDIMLAŞMA VE DAYANIȘMA VAKIFLARININ, AYLIK BAŞVURUSUNUN REDDİ VE AYLIĞIN KESILMESI İŞLEMLERININ İPTAL DAVALARINDA DAVALI IDARE}

İdari davalarda husumetin idari işlemi tesis eden veya idari eylemi yapan idareye yöneltilmesi gerekmektedirs4. İdari davaların doğru hasımla görülmesi, sağlıklı ve adil bir yargılama yapılmasını, doğru karar verilmesini etkiler. Buna ek olarak doğru hasmın tespit edilmesi, savunma hakkı ve mahkemenin kararının uygulanması açısından da oldukça önemlidir ${ }^{85}$. Ayrıca davada husumetin yanlış idareye yöneltilmesi halinde uyuşmazlığa konu işlemi tesis etmeyen idare, gereksiz yargılama süreci ile meşgul olacaktır. İşlemi tesis eden gerçek hasım olan idare ise yargılama sürecindeki işlemleri yapma imkânı bulamayacak ve taraf olamadığı için tesis ettiği işlem ile ilgili davada savuna yapama yacaktır ${ }^{86}$.

IYYUK' un 31'inci maddesinde husumet konusunda HMK' ya atıf yapılmadığı için kamu tüzel kişiliğine sahip olmayan idareler de idari yargı tarafından davalı olarak kabul edilmektedir. Bu durumda, iptal davalarında davalı idarenin uyuşmazlık konusu idari işlemi kesin ${ }^{87}$ olarak tesis eden idare olması yeterlidi $r^{88}$.

2022 sayılı Kanun'da, kamu gücü kullanma yetkisi verilen iki otorite bulunmaktadır. Bunlar, Aile ve Sosyal Hizmetler Bakanlığı ve SYD vakıflarıdır. Bakanlık, ödemeleri doğrudan ilgililerin hesaplarına yaparken, aylık başvurusunun reddi veya aylı̆̆ın kesilmesine ilişkin SYD vakıfları tarafından verilen kararları iptal edememekte ve değiştirememektedir.

\section{A. Aile ve Sosyal Hizmetler Bakanlığının Engelli ve Yaşlı Aylıkları ile İlgili Görevleri ve Yetkileri}

2022 sayılı Kanun ile Yönetmelik hükümleri birlikte dikkate alındığında, Bakanlığın aylık işlemleri ile ilgili görevlerini beş başlık altında toplamak mümkündür.

- Aylıkların Ödenmesi: Aylıklar, Aile ve Sosyal Hizmetler Bakanlığı tarafindan belirlenecek ödeme gün ve dönemlerinde peşin olarak ödenir (2022 sayılı Kanun m. 3/2).

- Aylık Başvurusunda Bulunanlar veya Aylık Almaya Hak Kazananlar ile Illgili Bilgi ve Belge İsteme: Aile ve Sosyal Hizmetler Bakanlığı ile SYD vakıfları, gerektiğinde, başvuranların ve bunlara nafaka ödeme sorumluluğu bulunanların gelir, servet ve yaşam standartları hakkında araştırma yapmaya ve yaptırmaya, kamu ve özel kişilerden bilgi ve belge istemeye yetkilidir (2022 sayılı Kanun m. 8).

- Uygulama Yönetmeliğini Yayımlama: 2022 sayılı Kanun'un 4'üncü maddesine göre, aylığa hak kazanma süreci ile aylığın ödenmesi sürecine dair kurallar ile bu süreçlerde kabul edilecek belge lere ilişkin bilgiler, Aile ve Sosyal Hizmetler Bakanlığı ile Hazine ve Maliye Bakanlığınca hazırlanacak yönetmelikle düzenlenir.

\footnotetext{
83 ÇAĞLAYAN, Ramazan: İdare Hukuku Dersleri, 3. Baskı, Adalet Yayınevi, Ankara, 2015, s. 420. Söz konusu, Danıştay kararı (10.D., T. 17.06.1991, E. 1991/1149, K. 1991/2286), TürkiyeFutbol Federasyonu ileilgilidir.

84 GÜNDÜZ, Fatma Ebru: İdari Davalarda Ehliyet ve Husumet, Yetkin Yayınları, Ankara, 2016, s. 222.

85 AKYILMAZ / SEZGINER / KAYA, Türk İdari Yargllama Hukuku, s. 371.

86 GÜNDÜZ, s. 223.

87 YILMAZ, Dilşat: “Türk İdare Hukuku'nda İdari İşlemin 'Kesin'liği Üzerine Bir Değerlendirme: 'Kime Göre?', 'Ne İçin?' Kesinlik”, Ankara Hacı Bayram Veli Üniversitesi Hukuk Fakültesi Dergisi, 2017, Cilt 21, Sayı 2, s. 109. "Kesinlik" idari işlemin idari usûl sürecinin tamamlanarak, idarenin iradesinin ortaya çıkmasıdır. SEZGINER, Murat: İptal Davasının Uygulanması Bakımından Ayrlabilir İ̧slem Kuramı, Yetkin Yayınları, Ankara, 2000, s. 46; ERKUT, s. 120.

88 GÜNDÜZ, s. 240; AKYILMAZ / SEZGINER / KAYA, Türk İdari Yargllama Hukuku, s. 374; TAN, s. 997.
} 
- Fazla ve Yersiz Ödenen Aylıkların Takip ve Tahsil Etme: Yönetmelik'in 16'ncı maddesine göre, aylığa hak kazanmak üzere düzenlenen belgelerin gerçeğe uymadığı tespit edildiği takdirde ödenmiş olan aylıklar için Aile ve Sosyal Hizmetler Bakanlığ tarafından borç tahakkuk ettirilerek takip ve tahsili sağlanır. Hak sahibinden tahsili imkânının kalmadığı durumlarda, Aile ve Sosyal Hizmetler Bakanlığı tarafından tahakkuk edilen borç, aylığın ödenmesinde kasıt, kusur veya ihmali olduğu tespit edilenlerden müteselsilen tahsil edilir.

- 2022 Sayılı Kanun Kapsamındaki İşlemleri Denetleme: Yönetmelik'in 17'nci maddesinin 4'üncü fikrasına göre, Aile ve Sosyal Hizmetler Bakanlığı Denetim Hizmetleri Başkanlığı tarafından her y1l, 2022 sayılı Kanun kapsamında yapılan ödemelere ilişkin olarak, ödeme türü, hak sahiplerinin ağırlıklı olduğu ikamet bölgeleri, sistemin sağladığı güvenlik dereceleri ve benzeri ölçütler üzerinden yapacağı risk değerlendirme sonuçlarına göre ve örneklem metoduyla belirlediği hak sa hiplerinin durumunu inceler ve sonuçlarını, uygulamaya yönelik önerileri içeren raporu hazırlar. Sosyal Yardımlar Genel Müdürlüğü, bu raporda yer verilen ve uygulamada tespit ettiği diğer yaygın uygulama hatalarını her yı1 SYD vakıflarına yazılı olarak bildirir.

\section{B. Engelli ve Yaş̧ı Aylıkları ile İlgili Aile ve Sosyal Hizmetler Bakanlığı ve Sosyal Yardımlaşma ve Dayanışma Vakıflarının Görev ve Yetkilerinin Karşılaştırılması}

Mevzuat hükümleri incelendiğinde, SYD vakıfları tarafindan tesis edilen aylık başvurusunun reddi işlemi ile aylığın kesilmesi işleminde Aile ve Sosyal Hizmetler Bakanlığı ile ilgili bir onay veya imza süreci bulunmadığı; diğer bir ifade idari usul sürecinde Bakanlığın yer almadığı anlaşılmaktadır. SYD vakıfları tarafından muhtaç olmama gerekçesiyle veya 2022 sayılı Kanun'daki şartlara aykırılık nedeniyle başvurunun reddi kararı verilmesi halinde Aile ve Sosyal Hizmetler Bakanlığının doğrudan aylık bağlamasını mümkün değildir. Buna ek olarak, anılan Bakanlığın, muhtaçlık kararı vermesi de söz konusu değildir.

Aylık başvurusunun reddi işleminden farklı olarak aylığın kesilmesi işleminde, 2022 sayılı Ka nun'un 8'inci maddesinin 2'nci fikrası ile Aile ve Sosyal Hizmetler Bakanlığı da yetkilendirilmiş olduğundan, Bakanlık tarafından tesis edilen aylığın kesilmesi işlemlerine karşı açılacak iptal davalarının Aile ve Sosyal Hizmetler Bakanlığı husumetiyle görülmesi gerekmektedir.

Bir kanun hükmü ile kamu hizmeti yürütme yetkisi ile yetkilendirilen özel hukuk tüzel kişilerinin de kamuya ait yetkilerle idari işlem yapabilmektedir. İptal davalarında davalı idare, ilgililerin menfaatini ihlâl eden işlemi tesis eden idaredir ${ }^{29}$. Bu hususlar birlikte göz önünde bulundurulduğunda, aylık başvurusunun reddi işlemi ile SYD vakıfları tarafından tesis edilen aylığın kesilmesi işlemlerinin iptali amacıyla idari yargıda açılacak davanın, ilgili SYD vakfı husumetiyle görülmesi gerekmektedir.

İdari yargı yerleri, davalı idare olarak Aile ve Sosyal Hizmetler Bakanlığ $1^{90}$, valilik, kaymakamlık ve ilgili SYD vakfına husumeti yöneltmekte ve birbirinden farklı kararlar vermeye devametmektedirler ${ }^{91}$.

89 AKYILMAZ / SEZGINER / KAY A, Türk İdari Yargllama Hukuku, s. 374.

90

Eski ismiyle Aile ve Sosyal Politikalar Bakanlı̆̆

91 Bursa 4. İdare Mahkemesi, T. 01.10.2019, E. 2019/244, K. 2019/62 sayılı kararına konu davayı, Aile ve Sosyal Hizmetler Bakanlı̆̆ husumetiyle görmüş ve Orhangazi SYD Vakfının işleminin iptali amacıyla açılan davanın görev yönünden reddine karar vermiștir. Konya 2. İdare Mahkemesi, T. 09.10.2019, E. 2018/1539, K. 2019/1170 sayılı kararına konu davayı, Beyşehir SYD Vakfi husumetiyle görmüs ve dava konusu işlemin iptaline karar vermiștir. Samsun 2. İdare Mahkemesi, T. 10.10.2018, E. 2018/1539, K. 2019/1170 sayıll ka rarına konu davayı, Vezirköprü SYD Vakfı husumetiyle görmüş ve davanın görev yönünden reddine karar vermiş̧tir. Tokat İdare Mahkemesi, T. 26.11.2020, E. 2020/617, K. 2020/818 sayılı kararına konu davay1, Aile ve Sosyal Hizmetler Bakanlığı ve Niksar Kayma kamlığı husumetiyle görmüş ve Niksar SYD Vakfının ișleminin iptali amacıyla açılan davanın görev yönünden reddine karar vermisștir. İstanbul 3. İdare Mahkemesi, T. 23.11.2018, E. 2018/1213, K. 2018/1911 sayılı kararına konu davay1, Aile ve Sosyal Hizmetler Bakanlı̆̆ı husumetiyle görmüş ve Zeytinburnu SYD Vakfının işleminin iptali amacıyla açılan davada, işlemin iptaline karar vermiștir. Bakanlığın yaptığı istinaf üzerine, İstanbul BİM, 8. İDD., T. 17.09.2019, E. 2019/476, K. 2019/940 sayılı kararı ile davanın ehliyet yönünden reddine karar vermiştir. Husumet itirazı hakkında İstanbul 3. İdare Mahkemesi ve İstanbul BİM, 8. İDD. değerlendirme yapmamıştır. İstanbul 12. İdare Mahkemesi, T. 23.02.2018, E. 2017/1114, K. 2018/345 sayılı kararına konu davayı, Aile ve Sosyal Hizmetler Bakanlı̆̆ husumetiyle görmüş ve Zeytinburnu SYD Vakfının işleminin iptali amacıyla açılan davada, işlemin iptaline karar vermiştir. Bakanlığın yaptığı istinaf üzerine, İstanbul BİM, 8. İDD., T. 02.10.2018, E. 2018/1310, K. 2018/1378 sayılı kararı ile davanın reddine karar vermiş- 


\section{SONUÇ}

Aile ve Sosyal Hizmetler Bakanlığ tarafından, 2022 sayılı Kanun kapsamında, 2019 yılı itibarıyla 1.543.540 kişiye engelli, engelli yakını ve yaşı aylığı ödenmektedir. Bu aylıkların başvuruları SYD vakıflarına yapılmaktadır.

2022 sayılı Kanun'un verdiği yetkiyle SYD vakıfları tarafından aylık başvuruları alınmakta, başvurucuların muhtaç olup olmadığı incelenmekte ve başvuruların kabulüne karar verilmektedir. Başvur ruları kabul edilip muhtaç olduğuna karar verilenlere Aile ve Sosyal Hizmetler Bakanlığı tarafından aylıklar ödenmektedir. Buna karşın, engelli ve yaşlı aylığı başvurularının çeşitli sebeplerle SYD vakıfları tarafından reddedilmesi neticesinde ilgililer, başvurunun reddi kararına karşı bu kararı veren SYD vakfına itiraz edebilmekte ve itiraz sonucunda verilen karar ile bu itirazlar hakkında nihai karar verilmektedir. Diğer bir ifadeyle aylık başvurusunun reddine karşı SYD vakfına yapılan itirazın reddedilmesi ile idari süreç sona ermektedir.

SYD vakıfları tarafından, engelli ve yaşlı aylığı alanlar hakkında inceleme yapılarak aylık alma şartlarını kaybedenlerin aylıkları kesilmektedir. Yine aynı şekilde, SYD vakıflarının aylığın kesilmesi yönündeki kararlarına karşı, kararı veren vakfa itiraz edilmesi mümkün olup itiraz sonunda verilen kararlar kesindir.

Aylık başvurusunun reddi kararları ile aylığın kesilmesi kararları, ilgililerin menfaatlerini ihlâl eden, tek taraflı ve icrai nitelikli işlemlerdir. İdari işlemin özellikleri ve unsurları dikkate alındığında, bu işlemler idare hukuku alanında tesis edilmiş ve iptal davasına konu olabilecek idari işlemlerdir.

Gerek Danıştay gerekse Uyuşmazlık Mahkemesi, bu işlemlerin bir özel hukuk tüzel kişisi tarafından tesis edilmesini, bir başka deyişle idari makamlarca tesis edilmemesini, esas alarak davalının ilgili SYD vakfı olduğuna karar vermektedir. Yine aynı gerekçe ile görevli yargı yerinin de adli yargı oldur ğu belirtilmektedir.

Hâlbuki SYD vakıfları, 2022 sayılı Kanun ile yetkilendirilmiş olup 2022 sayılı Kanun ve Yönetmelik çerçevesinde kamu hukuku alanında faaliyette bulunmaları nedeniyle idari işlem tesis edebilmektedir. Bu nedenle geniş anlamda idare kavramı içerisinde kabul edilmeleri hukuka uygun bir yaklaşımdır. Ayrıca bir özel hukuk tüzel kişisinin kamu hukuku alanında faaliyette bulunması durumunda, tesis edilen işlemlerin idari yargı alanı dışında kabul edilmesinin idarenin değil, idari işlemin yargılandı̆̆ı esasına aykırılık teşkil etmektedir.

UYM'nin, “... vakıfların Medeni Kanun hükümlerine tabi olarak kurulup faaliyette bulunmalarlnın öngörülmüs olması nedeni ile dava konusu işlemin kamu gücü kullanılmak suretiyle tesis edildiğinin kabulünün mümkün bulunmadığı" yönündeki kararı, 2022 sayılı Kanun kapsamında değerlendirildiğinde, idare hukuku esaslarına uygun değildir. SYD vakıfları tarafından ilgililerin aylığının kesilmesi ve aylık başvurularının reddedilmesi sonucunda, 2022 sayılı Kanun'un verdiği yetkiyle kamu gücü kullanılmış ve hak sahiplerinin menfaatleri ihlâl edilmiş olmaktadır. Aylık başvurusunun reddi ile aylığın kesilmesi işlemlerinin kamu gücüne dayanmadığı iddiası aynı zamanda bu işlemlerin özel hur kuk kurallarına göre yapıldığı anlamına gelmektedir ki açıklandığg üzere bu işlemler, kamu hukuku çerçevesinde, işlemleri tesis edenlerin iradesinden bağımsız olarak mevzuatın belirlediği şekilde ya pilmaktadır.

UYM'nin bu yaklaşımı nedeniyle, 2022 sayılı Kanun kapsamındaki idari işlemlerinden kaynaklanan uyuşmazlıkların adli yargıda görülmesi, davacılar için hak kayıplarına neden olabilecektir. Çünkü idari yargıda uygulanan re'sen araştırma ilkesinin ve idare tarafından idari işlem dosyasının mahke-

tir. Husumet itirazı hakkında İstanbul 12. İdare Mahkemesi ve İstanbul BİM, 8. İDD. değerlendirme yapmamıştır. Son olarak, Ankara 6. İdare Mahkemesi, T. 14.09.2021, E. 2021/1207 sayılı görevlilik kararına konu davayı, Yenimahalle Kaymakamlığı ve Aile ve Sosyal Hizmetler Bakanlığı husumetiyle görmüş ve Yenimahalle SYD Vakfının işleminin iptali amacıyla açılan davada, görev itirazını reddede rek görevlilik kararı vermiştir. 
meye sunulması zorunluluğunun adli yargıdaki hukuk davalarında olmaması, elinde yeterli delil olma yan davacıların aleyhine bir durumun ortaya çıkmasına neden olabilecektir. Bu uyuşmazlıklarda, adli yargının görevli olduğunun kabulü halinde mahkeme kararlarının yerine getirilmesi ayrı bir sorun olarak ortaya çıkacaktır. Adli yargı yerinin kararı, delil niteliğinde bir belge olarak kalacak ve Aile ve Sosyal Hizmetler Bakanlığının aylık ödemesi için 2022 sayılı Kanun uyarınca ilgili SYD vakfının kararı aranmaya devam edilecektir.

Bir buçuk milyondan fazla kişi 2022 sayılı Kanun kapsamında engelli, engelli yakını ve yaşlı aylığ almaktadır ve Aile ve Sosyal Hizmetler Bakanlığı tarafından, aylık alanların sayısının her yıl arta cağı öngörülmektedir. Bu durum, aylıklar ile ilgili uyuşmazlıkların hangi yargı yerinde çözümlenmesi gerektiği konusunu daha da önemli hale getirmektedir. Bu çerçevede, aylık başvurunun reddi ile aylıkların kesilmesi kararlarından doğan uyuşmazlıkların, idari yargıda açılacak bir iptal davası ile bu işle mi tesis eden otorite sıfatıyla ilgili SYD vakfı veya aylığın kesilmesi işleminin Bakanlık tarafindan yapıldığı durumlarda Aile ve Sosyal Hizmetler Bakanlığı husumetiyle çözümlenmesinin hukuka en uygun yöntem olduğu sonucu ortaya çıkmaktadır. 


\section{KAYNAKÇA}

Aile, Çalışma ve Sosyal Hizmetler Bakanlı̆̆ı, 2021 Yılı Performans Programı, 2021, s. 131-132. (https://www.aile.gov.tr/media/72689/acshb-2021-yili-performans-programi.pdf, E.T.: 21.11.2021).

AKIPEK, Jale / AKINTÜRK, Turgut / ATEŞ, Derya: Türk Medeni Hukuku, 1. Cilt, 16. Baskı, Beta Basım Ya yin, İstanbul, 2020.

AKYILMAZ, Bahtiyar / SEZGINER, Murat / KAYA, Cemil: Türk İdare Hukuku, 9. Baskı, Savaş Yayınevi, Ankara, 2018 (Türk İdare Hukuku).

AKYILMAZ, Bahtiyar / SEZGINER, Murat / KAYA, Cemil: Türk İdari Yargılama Hukuku, Savaş Yayınevi, Ankara, 2018 (Türk İdari Yargılama Hukuku).

ATAY, Ender Ethem: İdare Hukuku, 6. Bask1, Turhan Kitabevi, Ankara, 2018.

AY KUL, Ömer: Yeni Vakıflar Hukuku, Seçkin Yayıncılık, Ankara, 2013.

CANDAN, Turgut: Açıklamalı İdari Yargılama Usûlü Kanunu, 5. Baskı, Adalet Yayınevi, Ankara, 2012.

ÇAĞLAYAN, Ramazan: İdare Hukuku Dersleri, 3. Baskı, Adalet Yayınevi, Ankara, 2015.

EM, Ali: Türk Hukuk Sisteminde Vakıflar, Turhan Kitabevi, Ankara, 2006.

ERKUT, Celal: İptal Davasııın Konusunu Oluşturma Bakımından İdari İşlemin Kimliği, Danıştay Matbaası, Ankara, 2015.

GÖZLER, Kemal / KAPLAN, Gürse: İdare Hukuku Dersleri, 18. Bask1, Ekin Kitabevi, Bursa, 2016.

GÜNDÜZ, Fatma Ebru: İdari Davalarda Ehliyet ve Husumet, Yetkin Yayınları, Ankara, 2016.

İSBİR, Kevser Begüm: Kamu Tüzel Kişiliği, Turhan Kitabevi, Ankara, 2017.

OĞUZMAN, Kemal / SELIÇİ, Özer / OKTAY-ÖZDEMIR, Saibe: Kişiler Hukuku Gerçek ve Tüzel Kişiler, 17. Bask1, Filiz Kitabevi, İstanbul, 2018.

ÖĞÜZ, Mehmet Tufan: Türk Hukukunda Vakıf Tüzel Kişiliğinin Hukuki Esasları, Beşir Kitabevi, İstanbul, 2007.

SANCAKDAR, Oğuz / US, Ender / KASAPOĞLU TURHAN, Mine / ÖNÜT, Lale Burcu: İdare Hukuku Teorik Çalışma Kitabı, 5. Baskı, Seçkin Yayıncılık, Ankara, 2015.

SEROZAN, Rona: Medeni Hukuk Genel Bölüm Kişiler Hukuku, 8. Baskı, Vedat Kitapçılık, İstanbul, 2018.

SEZGINER, Murat: Iptal Davasının Uygulanması Bakımından Ayrılabilir İşlem Kuramı, Yetkin Yayınları, Ankara, 2000.

PEKCANITEZ, Hakan / ATALAY, Oğuz / ÖZEKES, Muhammet: Medeni Usûl Hukuku Ders Kitabl, 8. Baskı, On İki Levha Yayınc1lık, İstanbul, 2020.

TAN, Turgut: İdare Hukuku, 2. Bask1, Turhan Kitabevi, Ankara, 2013.

TANRIVER, Süha: Medeni Usûl Hukuku, Cilt 1, 2. Baskı, Yetkin Yayınları, Ankara, 2018.

YILMAZ, Dilşat: İdari İşlemin İcrailik Özelliği, Astana Yayınları, Ankara, 2014 (İcrailik Özelliği).

YILMAZ, Dilşat: “Türk İdare Hukuku'nda İdari İşlemin “Kesin”liği Üzerine Bir Değerlendirme: “Kime Göre?”, "Ne İçin?” Kesinlik", Ankara Hacı Bayram Veli Üniversitesi Hukuk Fakültesi Dergisi, 2017, Cilt 21, Sayı 2, s. $105-154$. 